\title{
Debt Issues and Earnings Management ${ }^{\star}$
}

Bianca Piloto Sincerre

Pontifícia Universidade Católiça de São Paulo, Programa de Estudos Pós-Graduados em Adminisțração, São Paulo, SP, Brazil

Joelson O. Sampaio

Fundação Escola de Comércio Álvares Penteado, Departamento de Administração, São Paulo, SP, Brazil

\section{Rubens Famá}

Universidade de São Paulo, Faculdade de Economia, Administração e Contabilidade, Departamento de Administração, São Pauḷ, SP, Brazil

José Odálio dos Santos

Pontifícia Universidade Católica de São Paulo, Departamento de Administração, São Paulo, SP, Brazil

Received on 02.08.2015 - Desk Acceptance on 03.24.2015 - 5th version approved on 03.12.2016.

\section{ABSTRACT}

The aim of this paper is to analyze earnings management (EM) surrounding debenture issues of companies listed on the BM\&FBOVESPA. $\mathrm{EM}$ is an intentional intervention in external financial reports in order to obtain some private gain. This practice is especially important at the time of issuing debentures because if earnings are inflated, investors may pay an artificially high price. To measure earnings management, current discretionary accruals were used as a proxy, based on the Modified Jones and Modified Jones with ROA econometric models. All of the regressions considered the fixed effects of the companies and the time series effects of the analyses. Evidence was found that companies inflate their financial results in the issuing period in order to positively influence their investors. The results suggest that there is EM in the quarter preceding the issue $(t=-1)$, indicating the influence that investors may have been under. when making the decision to invest in debentures from these companies. In addition, it was verified that companies with higher debt, profitability, and sales growth ratios have higher levels of earnings management. The reputation of the auditor was not statistically significant regarding reductions in the level of management. The results also show that companies listed on Level II and New Market had higher levels of management when considering the Modified Jones with ROA model. Therefore, it can be concluded that there is a greater level of earnings management in companies that issue debentures in the period preceding the event. Finally, the variable that is directly related to the level of earnings management is sales growth.

Keywords: earnings management, debenture, capital market. 


\section{INTRODUCTION}

Company accounting reports contain information of a financial and economic nature, which can undergo adjustments carried out by managers. People with different needs and incentives may use freedoms allowed by law in order to serve private interests. The possibility of exercising discretion allows managers freedom in measuring company accounting results, which is known as Earnings Management (EM). These interventions in results occur within accounting norms and principles, based on flexibility regarding the choice of certain accounting procedures.

The possibility of earnings being managed can cause serious problems, since the interpretation of accounting reports and the measurement of company profitability become a combination between evaluating the company's economic reality and identifying the possible adjustments that may have been made.

Due to accounting data containing important information that is used by a wide set of users (stakeholders), creditors use reported figures to evaluate companies in aspects related to financial health, credibility, and viability (Ge, 2009). With regards to shareholders, they monitor operational performance based on, among other indicators, income. However, if shareholders cannot identify the effect of earnings management in financial statements, their interpretation regarding company performance may be mistaken. This bias will be revealed in future results, when company performance turns out to be very different from the estimations that were made (Cupertino, 2013).

The opportunity to manage financial reports is appealing to the executives of publicly-traded companies. The causes that can contribute to this questionable behavior are many and include, notably: (i) the desire to keep their position, even if this implies compromising the quality of reported financial results; (ii) pressure from shareholders for ever greater and better quarterly results, as well as the wish to attract new investors and shareholders; and (iii) the ambition to obtain a significant bonus (compensation), even if this implies future sacrifice for the organization (Martinez, 2001).

On this point, certain accounting choices are made with the intention of misleading users with regards to real company economic-financial performance, in the desire to obtain some private gain. This practice is especially important at the time of issuing debentures, because if earnings are inflated, investors can pay an artificially high price for these securities.

Studies carried out in Brazil have found strong evidence that executives have manipulated their results in response to capital market incentives.

Martinez (2001) made important contributions with respect to earnings management. The author demonstrated, empirically, that publicly-traded Brazilian companies managed their financial results in response to capital market incentives. In terms of market performance, he found that companies that artificially managed earnings were able to attract investors; however, in the long run, the market identified the procedure, pricing this practice and penalizing shares with worse cumulative performance.

Coelho and Lopes (2007) examined the existence of earnings management and its connection with the degree of leverage in publicly-traded Brazilian companies. By means of the Modified Jones model, the authors found the existence of EM in the samples examined, although this practice did not confirm, through statistical data, its relationship with levels of debt.

Schipper (1989) and Iudícibus and Lopes (2004) found evidence of the relationship between leverage and the level of company earnings management. These authors indicated that more indebted companies exhibited higher levels of EM in their financial reports, in order to generate some private gain. Nardi and Nikao (2009) highlight that, due to contractual motives and the need to acquire more favorable loans, companies can be stimulated into managing their earnings.

Martinez and Faria (2007) investigated whether companies that issued debentures in Brazil promoted earnings management with the intention of altering investors' risk perceptions. The results of this study showed indications of EM in the sample companies; however, they did not investigate what the EM dynamic was in the debenture issuing process. In other words, they did not analyze at which moment financial results were inflated in these companies and which operational and financial variables could be related with EM at the time of issue.

This subject has been developed and published in international journals more and more, expanding Brazilian academics interest in it, both from the theoretical perspective as well as that of empirical observation. However, there are some gaps in these studies at the Brazilian level. One of these is in analyzing the relationship between earnings management and the process of issuing debt securities (debentures).

Accounting, in providing information to the market, performs an important role in managing conflicts of interest and reducing information asymmetry. After all, according to Easley and O'Hara (2004), concise accounting information reduces investor risk and proposes a relationship between the quality of information available and the returns demanded by company fund providers.

Managing company earnings in order to improve them can lead users of financial information to make a mistaken analysis regarding true economic-financial performance. This study may provide evidence that managers are inflating company results in debenture issuing periods and masking real company performance.

The study is justified, in theory and practice, by con- 
tributions to academic knowledge, enriching the Brazilian literature regarding the inter-relationship between earnings management and the issuing of debt securities, specifically debentures, as well as supporting the investigation into the earnings management dynamic. Another incentive for the development of this study is indicated by Iudícibus and Lopes (2004). The authors claim that the study of financial accounting, primarily in a country with particular features such as Brazil, may favor a more detailed understanding of the real incentives behind managers' actions.

With that in mind, this paper studies the earnings management dynamic surrounding the event of issuing debt securities (debenture) by companies listed on the BM\&FBOVESPA, with the main aim of evaluating EM practices in debenture issuing periods, as well as identifying in which debenture issuing period this intervention is carried out. Therefore, the study is not limited to verifying whether more or less EM occurs in companies that issue debentures and those that do not.

After a brief review of some studies that are impor- tant to the proposed subject, it becomes evident that earnings management practices affect the quality of income, masking underlying economic transactions. When control mechanisms (auditors and regulatory bodies, among others) are lacking, opportunities arise for managers to manipulate earnings with the intention of achieving targets in relation to reported results, such as meeting analyst expectations, avoiding losses, maintaining trends for growth, or "smoothing" the level of reported income (Healy \& Wahlen, 1999).

Thus, the study may assist various stakeholders in terms of identifying possible EM practices. Companies that have less volatile results give users more confidence, making them lower risk, improving the risk-return ratio, and consequently raising their value. Moreover, earnings management can be seen as a practice that harms future minority shareholders, since gains obtained with the artificial overvaluation of reported earnings are enjoyed by controllers, while the onus remains on (minority) shareholders who join at the time of acquiring debt securities.

\section{LITERATURE REVIEW}

\subsection{Earnings Management}

Earnings Management has aroused interest among different researchers regarding various aspects: to what extent company earnings are inflated; the quality of financial information disclosed by companies; and also the effectiveness of accounting norms and standards created with the aim of protecting shareholders who act based on these statements.

According to Martinez (2001), manipulations in financial statements compromise the quality of accounting information, possibly affecting the investments allocated to different companies. Moreover, this practice can cause unmeritorious distribution of wealth, since investors with better information can increase their wealth at the expense of investors with poorer information. This often occurs as a result of the degree of subjectivity resulting from flexibility in accounting practices.

According to Scott (2011), management can use earnings management to report a smooth and rising flow over time. Given the efficiency of the stock market, this results in management taking advantage of privileged (insider) information, making earnings management a means of communicating insider information to investors. Interpreting it in this way, income smoothing leads to the interesting conclusion that some earnings management may be useful, from a financial reports point of view (Scott, 2011).

However, excess earnings management may reduce the usefulness of these financial reports for investors. This is especially true if earnings management is not totally disclosed. Moreover, earnings management can affect managers' motivation to work hard, as a result of using EM as an instrument to facilitate their remuneration over time, reducing the risk of compensation (Scott, 2011).

Once managers can choose accounting policies based on a set of policies, it is natural to expect them to adopt those that help them to achieve their objectives. They may also take real measures that affect income, such as cutting Research \& Development (R\&D) costs. These choices can be motivated not only by market efficiency and contracts (discussed further on), but also by opportunism and the rejection of market efficiency. Therefore, for Scott (2011), earnings management can be understood as a choice of accounting policies or real actions that affect earnings, in order to achieve some specific objective.

Healy and Wahlen (1999) claim that earnings management occurs when managers use their judgment in financial information and in the structuring of operations in order to alter financial reports, whether to mislead some interested parties with regards to company economic performance, or to influence contractual results that depend on reported accounting figures.

The authors indicate some implications of this definition. First, there are different ways for managers 
to exercise their judgment in financial reports, that is, there is not only earnings management via accounting choices, but also via real or operational decisions which can also be used in the issuing of debentures. Moreover, judgment is needed to estimate countless future economic events, such as residual asset values in the long run, deferred taxes and bad debt losses, or asset impairment. Managers must also choose between accounting methods that are acceptable for reporting the same economic transactions; exercise judgment in the control of working capital, which can affect the allocation of costs and net revenues; and opt to incur or postpone R\&D or advertising expenses.

The second point to highlight is that the definition given by Healy and Wahlen (1999) defines the aim of earnings management as misleading stakeholders with regards to real company economic performance. Moreover, this may also occur if managers have access to information that is not available to external stakeholders, making earnings management transparency improbable. Thus, stakeholders are liable to expect (and tolerate) a certain amount of earnings management.

Managers can also use their accounting judgment to elaborate more informative financial reports for users. This can occur if certain accounting choices or estimates are perceived as credible signs of company financial performance.

Finally, management use of judgment in financial information, according to Healy and Wahlen (1999), has costs and benefits. The costs are poor allocation of funds that arise as a result of earnings management. The benefits include potential improvements in the management of private information for external stakeholders, improving fund allocating decisions. Therefore, it is essential to understand when norms allow managers to exercise judgment to report an increase in the value of accounting information for users, and when they allow a decrease in it to be reported.

Dechow, Sloan, and Sweeney (1995) discuss techniques for detecting earnings management: (i) changes in accounting procedures; (ii) use of discretionary cash flow elements ( $R \& D$ and advertising costs; accelerating or postponing receipt from sales); and (iii) discretionary accounting adjustments related to accruals (increasing or reducing bad debt provisions and recognizing revenue in advance).

There are different models that aim to indirectly measure the level of EM in companies, since it is not directly observable. Generally, these models are based on accruals, which would be the difference between net income and net cash flow from operations. Total accruals can be divided into short term (current) and long term (non-current) components. Adjustments in current accruals only consider changes in current assets and liabilities, which support short term company operations. These adjustments can be made, for example, by means of recognizing sales revenues before the entry of the respective amount into cash flow; through delaying the recognition of expenses, by means of a small provision for bad debts; and deferred recognition of expenses when money is paid to suppliers in advanced. Adjustments in non-current accruals involve long term liquid assets. In this case, the examples would be: non-accelerated depreciation, reduction in deferred taxes, and achievement of abnormal earnings. Due to the fact that managers have greater access, current accruals are usually used as a basis for earnings management (Teoh, Welch, \& Wong, 1998).

After this brief discussion, the reason managers inform investors of the real underlying economic situation of companies is examined. The real incentives for earnings management are commented on by different international authors, especially Healy and Wahlen (1999), who present the three main ones: (i) motivations linked to the capital market - the wide use of accounting information by investors and analysts creates an incentive for managers to administer accounting results. The aim is to alter the perception of risk regarding investments in company shares; (ii) contractual motivations and regulatory motivations - earnings management practices can be tied to compensation packages. Accounting data is used to help monitor and regulate contracts between companies and their various stakeholders. Explicit and implicit remuneration contracts are used to align executives' incentives and those of external stakeholders; and (iii) political costs.

Healy (1985) indicates that executives who receive part of their remuneration as bonuses "inflate" accounting results, in order to increase their compensation. This last motivation may be related to decreases in monopolists' incomes, or to avoiding taxes and antitrust rules.

Other interpretations regarding the subject provide important contributions. The study carried out by Jones (1991) showed that firms that benefit from tariff protection try to reduce income by adopting EM practices. The results did not reject the hypothesis that managers adopt income reducing practices in periods in which they are being investigated, in order to create tariff protection. The Jones Model stood out in the academic literature in identifying the value of discretionary accruals. Burgstahler and Dichev (1997) also found evidence that two components of income - cash flow from operations and changes in working capital are used to achieve an increase in income. The authors also claim that companies manage earnings to avoid losses and to maintain results.

Different studies relate earnings management to IPOs. Teoh et al. (1998) observed that EM surrounding the date of an IPO is higher for companies that issue shares, in comparison with companies that do not. However, in using annual data, the authors did not capture the EM dynamic. Their results were probably underestimated, because inflation of financial results and subsequent reversion can occur in the same financial year, and therefore not be reflected in annual reports. 
Rangan (1998) studied the effect of EM in the subsequent share performance of companies that carried out a new public share offering. The author found inflated earnings in the quarter near to the SEO (Seasoned Equity Offering) announcement and in the subsequent quarter. However, the author limited himself to comparing the median value of discretionary accruals in each quarter, without controlling other variables that could affect the level of EM, such as size, sales growth, and leverage.

Hochberg (2012), based on a sample of annual data on IPOs in the United States, found evidence that IPOs of companies invested in through Private Equity and Venture Capital (PE/VC) exhibit reduced EM. The author argues that larger companies have more complex financial statements, and therefore exploit this aspect to manage earnings. On the other hand, larger companies are also more subject to being monitored by market analysts, and this reduces the opportunities for EM.

Gioielli, Carvalho, and Sampaio (2013) showed that in IPOs of companies with PE/VC investment, EM is marginal, generally related to company characteristics, and of little relation to the phases of IPO. In contrast, in IPOs of companies not invested in through PE/VC, EM is significant, generally related to the phases of IPO, and of little relation to company characteristics.

Other studies relate earnings management with the degree of company indebtedness. Iudícibus and Lopes (2004) provided evidence of the Level of Indebtedness Hypothesis, in which more leveraged companies are predisposed to choosing accounting methods that stimulate increases in reported income, given that there is an interest in attracting investors to the business. Schipper (1989) had already found this relationship, suggesting that this intentional intervention in the financial reporting process could generate private gains. $\mathrm{An}, \mathrm{Li}$, and $\mathrm{Yu}$ (2013) also analyzed the effect of EM in financial leverage. The study aimed to verify how the EM/leverage relationship is influenced by institutional environments. Evidence was found that companies involved in high levels of earnings management have, on average, greater leverage. This may be linked to the fact that a company's EM reflects conflicts of agency between managers with privileged information and external investors.

\subsection{Earnings Management and Debt Security Issues}

Debt security holders tend to concentrate on a company's ability to generate future cash flow to guarantee the payment of debt interest and principal. The quality of accounting information affects debt holders' future cash flow estimates. Bharath, Sunder, and Sunder (2008) found that companies with compromised accounting quality face significantly higher yield differentials for new debt security issues. Prevost, Rao, and Skousen (2008) reported that abnormal accruals have negative impacts on the prices of all debt securities. These results suggest that creditors demand a higher rate from companies that manage earnings via accruals.

Nardi and Nakao (2009) studied the relationship between earnings management and the cost of debt for publicly-traded Brazilian companies. The assumptions made based on the existing literature are that, seeking better contractual conditions, such as the cost of debt, current or past cost motivates a company to manage current earnings to obtain better future or current cost conditions. Thus, companies would intentionally aim to manage their earnings, motivated by the cost of debt. The results indicated that there is a positive relationship and the greater EM is, the higher the cost of debt.

Nardi and Nakao (2009) indicate that contractual motivations and the need to acquire favorable (for example, low cost) loan conditions are motivations for companies to manage their earnings. In this sense, debenture issuing companies exhibit incentives to manage their accounting results. Thus, the first hypothesis aimed to test whether companies that issue debentures exhibit a higher level of EM in relation to those that do not.

$H_{1}$ : Debenture issuing companies exhibit a greater level of positive earnings management compared to non-issuing ones.

The first hypothesis is important because it shows whether there is a difference in behavior in relation to the level of EM between debenture issuing companies and non-issuing ones. This hypothesis aimed to verify whether the sample of debenture issuing companies is different to the sample of non-issuing ones.

Given that debenture issuing companies could have incentives to increase their level of earnings management in the issuing period, hypothesis 2 aimed to verify which stage this increase would occur in. With this in mind, the following hypothesis was formulated:

$\mathrm{H}_{2}$ : Debenture issuing companies exhibit a greater level of positive earnings management at the time preceding the issue, compared with non-issuing ones.

Considering that debenture issuing companies may exhibit a greater level of EM in one of the issue phases, hypothesis 3 aimed to identify which company characteristic variables (size, sales growth, ROA, leverage) could explain this greater level of EM. Hochberg (2012) argues that financial variables can exhibit a positive relationship with the level of company EM. Thus, this hypothesis aimed to test what the company financial characteristics are that could explain a greater level of EM in the debenture pre-issue period. With this in mind, hypothesis 3 was formulated as shown below:

$H_{3}:$ Debenture issuing companies exhibit different financial and operational characteristics at the time prece- 
ding the issue, compared to non-issuing ones.

According to Ge and Kim (2014), manipulated income should not be used as a reliable measure of company performance for debt security holders, with the aim of evaluating the future performance of a company. In this sense, EM distorts the quality of income and increases information asymmetry with regards to company performance between managers and debt security holders.

Evidence proves that the effect of earnings management in the debt securities market is important for various reasons. First, EM appears to be a common practice. Graham, Harvey, and Rajgopal (2005) suggest that $80 \%$ of participants in the study, executives of US companies, opted to implement real economic actions that could have negative consequences in the long run, instead of making accounting adjustments to achieve income targets in the short run.

Second, EM can hide non-managed company earnings, in which it can be harmful for company profitability and competitive advantages in the long run (Cohen \& Zarowin, 2010; Zang, 2012). Therefore, EM increases information asymmetry between managers and debt security holders in relation to the current non-managed period for a company, and can therefore affect debt security holder estimates as a result of managers boosting company income.

This informational risk has a potential effect on the price of securities. This aspect is supported in the study by Liu, Ning, and Davidson III (2010), which found evidence that earnings management increased before companies offered debt securities to the market. The results indicated that, as shareholders, security holders cannot see through inflated income when pricing a new debt.

Finally, debenture holders have set contractual claims, such as periodic interest payments. They tend to concentrate on future cash flows to guarantee company's ability to pay debt interest and principal. This occurs because EM can have direct negative consequences on the future level of net cash flows (Graham et al., 2005; Kim \& Sohn, 2013), and debenture holders are prone to being concerned about knowing about real earnings management activities.

\section{STUDY METHOD AND PROCEDURES}

The methodology developed for this paper is carried out by means of panel data regressions, making it possible to study the question from a time series perspective. Therefore, as well as investigating whether companies manage their accounting results, we also analyze at what time around issuing debt securities this practice is most intense.

\subsection{Population and Sample}

The database used in this paper is taken from the National Debentures System (Sistema Nacional de Debêntures - SND), accessible via the website linked to the Brazilian Association of Financial and Capital Market Entities (Associação Brasileira das Entidades do Mercado Financeiro e de Capitais - ANBIMA). The SND has records since 1981, with daily updates. This study is based on the period from January 2010 to January 2014. The company financial data is taken from the Economática ${ }^{\oplus}$ tool and quarterly company financial statements, available on the website of the Securities \& Exchange Commission (Comissão de Valores Mobiliários - CVM) for the BM\&FBOVESPA.

Taking into consideration that the empirical tests should be carried out on the variations in earnings management of debenture issuing companies, to begin with, listed companies that were privately held at the time of issuing debentures were excluded. Next, issues carried out by financial institutions, such as leasing companies, were removed from the sample. This exclusion is considered as standard in the literature due to the fact that this segment has particular risks and activities. Finally, companies whose balance sheets were not available in the specific quarter were excluded. In the end, the sample was composed of 180 companies, with 121 non-issuing companies and 59 debentures issuing companies. Considering the total of 302 companies listed on the BM\&FBOVESPA in 2014, the sample in the study represents $60 \%$ of the companies.

\subsection{Earnings Management Measures}

In the literature, various models have been developed to indirectly measure the level of EM in companies, with the majority based on accruals analysis (Healy, 1985; Jones, 1991; Dechow et al., 1995; Kothari, Leone, \& Wasley, 2005). Generally, these models are based on accruals that would be the difference between net income and net cash flow from operations. Total accruals can be divided into short term (current) and long term (non current) components. Adjustments in current accruals only consider changes in current assets and liabilities, which support short term company operations. These adjustments can be made, for example, via the recognition of sales revenues before the entry of the respective amount into cash flow; via postponing the recognition of expenses, by means of a small provision for bad debts; and deferred recognition of expenses when 
money is paid to suppliers in advance.

To estimate current discretionary accruals, two econometric models were used in this study: the Modified Jones Model (Dechow et al., 1995 with adjustments suggested by Kothari et al., 2005) and the Modified Jones Model with ROA (Dechow et al., 1995 with adjustments suggested by Kothari et al., 2005).

Dechow et al. (1995) created the Modified Jones model in an attempt to reduce increases in receivables from variations in sales, since they assume that there is the possibility of manipulating sales made on credit. Thus, the model excludes growth of receivables, identifying them as manipulation in the period.

The difference between the Modified Jones and the Modified Jones with ROA models is that the second one uses a new control for estimating non-discretionary accruals. As well as considering the net revenue and receivables variables, the model considers the return on assets (ROA) variable in the estimation of non-discretionary accruals.

In the Modified Jones Model, current accruals are given by:

$$
\frac{\text { Current_Accruals }_{i, t}}{T A_{i, t-1}}=\beta_{1}\left(\frac{1}{T A_{i, t-1}}\right)+\beta_{2}\left(\frac{\left(N R_{i, t}-N R_{i, t-1}\right)-\left(R_{i, t}-R_{i, t-1}\right)}{T A_{i, t-1}}\right)+\varepsilon_{i, t}
$$

In which:

Current_Accruals $s_{i, t}\left(C A_{i, t}-C A_{i, t-1}\right)-\left(C L_{i, t}-C L_{i, t-1}\right)$; $C A_{i, t}$ is the current assets of company $i$ in quarter $t$; $C L_{i, t}$ is the current liabilities of company $i$ in quarter $t$; $R_{i, t}$ are the receivables of company $i$ in quarter $t$; $N R_{i, t}$ are the net revenues of company $i$ in quarter $t$; $T A_{i, t}$ are the total assets of company $i$ in quarter $t$.
To estimate the current non-discretionary accruals for company $i$ in quarter $t$, the regressions for the sample considered in the study were determined. Based on the estimated non-discretionary accruals, it was possible to calculate the discretionary accruals. Using the Modified Jones Model, the current discretionary accruals (EM) are calculated by:

$$
\text { Discretionary_Accruals }_{i, t}=\frac{\text { Current_Accruals }_{i, t}}{T A_{i, t-1}}-\hat{\beta}_{1}\left(\frac{1}{T A_{i, t-1}}\right)-\hat{\beta}_{2}\left(\frac{\left(N R_{i, t}-N R_{i, t-1}\right)-\left(R_{i, t}-R_{i, t-1}\right)}{T A_{i, t-1}}\right)
$$

In which:

Discretionary_Accruals ${ }_{i, t}$ represent the EM for company $i$ in quarter $t$, which is calculated as the difference between the $C A_{i, t}$ variables (current accruals weighted by total assets in $\mathrm{t}-1$ and non-discretionary accruals [resulting from the estimation of betas in the model (1)]).

According to Guay, Kothari, and Watts (1996), the simple regression of return on discretionary accruals suggests that the Modified Jones model produces consistent discretionary accruals both with the improvement of performance as well as with opportunistic income smoothing.

In the Modified Jones Model with ROA, current accruals are specified by:

$$
\frac{\text { Current_Accruals } i_{i, t}}{T A_{i, t-1}}=\beta_{1}\left(\frac{1}{T A_{i, t-1}}\right)+\beta_{2}\left(\frac{\left(N R_{i, t}-N R_{i, t-1}\right)-\left(R_{i, t}-R_{i, t-1}\right)}{T A_{i, t-1}}\right)+\beta_{3}\left(R O A_{i, t}\right)+\varepsilon_{i, t}
$$

In which:

$R O A_{i, t}$ is the return on assets of company $i$ in quarter $t$.

\subsection{Econometric Specification}

To test hypothesis $H_{1}$, panel regressions were used, in which the dependent variable is the level of earnings management $\left(E M_{i, t}\right)$ for company $i$ in time $t$, measured by current discretionary accruals. The variable of interest is a dummy for companies that issued debentures. This variable is constant over time and takes the value 
of one (1) when the observation is from a company that issued debentures at moment $t$. To confirm $\mathrm{H}_{1}$, the coefficient of this variable should be positive and statisti- cally significant. The econometric model also includes different control variables that can influence the incentives for earnings management.

$$
\begin{gathered}
E M_{i, t}=\beta_{0}+\beta_{1} \text { Debenture }_{i}+\beta_{2} \text { Auditor }_{i}+\beta_{3} \text { Size }_{i, t}+ \\
\beta_{4} \text { Growth }_{i, t}+\beta_{5} \text { Leverage }_{i, t}+\beta_{6} \text { ROA }_{i, t}+\beta_{7} \text { Governance }_{i}+ \\
\gamma^{\prime} \text { quarter }_{t}+\delta^{\prime} \text { industry }_{j}+\varepsilon_{i, t}
\end{gathered}
$$

In which:

Debenture: is the dummy variable that takes the value of one (1) if company $i$ issued debentures, and zero (0) if not;

Auditor: is the dummy variable that takes the value of 1 if company $i$ had its financial statements audited by one of the market leaders (big four), and 0 if not;

Size $_{i, t}$ is the natural logarithm of total assets of company $i$ in quarter $t$ (in millions of reais);

Growth: is the variation in net revenue from operations of company $i$ between quarters $t-1$ and $t$, divided by net revenue from operations in quarter $t-1$;

Leverage $_{i, t}$ : leverage of company $i$ in quarter $t$, calculated as one minus the ratio between net equity and total assets;

$R O A_{i, t}:$ return on assets of company $i$ between quarters $t-1$ and $t$, calculated as the ratio between net income and total assets;

Corporate Governance: dummy variable that takes the value of 1 if company $i$ is listed on Level 2 or New Market of the BM\&FBOVESPA, and 0 if not;

$\gamma^{\prime}$ quarter: $^{\prime}$ is the vector of parameters that controls by quarters;

$\delta^{\prime}$ industry: is the vector of parameters that controls by sectors (Economática).

The Auditor ${ }_{1}$ variable has the effect of external monitor, working as a certification agent, which can restrain companies' EM. For Morsfield and Tan (2006), the external auditor's reputation could be damaged if they are not able to identify accounting distortions. Because of this, the expected result for the Auditor ${ }_{i}$ variable is negative.

The Size $_{i, t}$ variable can have a positive or negative effect on EM. For Hochberg (2012), the financial statements of larger companies are more complex, a factor that could facilitate earnings management. However, these companies are also subject to being monitored by market analysts, which could reduce opportunities for EM.

The result expected for the Growthi variable is positive. For Hochberg (2012), companies with higher growth rates are more prone to presenting higher levels of discretionary accruals, since they present a higher margin for EM.

Similar to the $S_{i z e}$ variable, there is no clear expectation for the Leverage ${ }_{i, t}$ variable. However, for Morsfield and Tan (2006), more leveraged companies have incentives to positively manipulate earnings, with the intention of avoiding violating debt contract clauses; nevertheless, these companies also face greater monitoring from debt holders. Moreover, Schipper (1989) and Iudícibus and Lopes (2004) provided evidence that companies with high levels of leverage also exhibited higher levels of EM.

The $R O A_{i, t}$ variable aims to control potential bias between EM and company performance. For Dechow et al. (1995), the earnings management tests can be badly specified if discretionary accruals are correlated with company performance.

The result expected for the Corporate Governance ${ }_{i}$ variable is negative. For Bowen, Rajgopal and Venkatachalam (2008), a low level of Corporate Governance can benefit earnings management, since there can be information asymmetry between shareholders and company managers.

To test hypothesis $\mathrm{H}_{2}$, which takes possible differences in the level of EM over time into consideration, the same basic specification of Model 4 was used, with the addition of dummy variables indicative of all the phases of issuing debentures. To confirm $\mathrm{H}_{2}$ the coefficient of one of the phase dummy variables should be positive and statistically significant. The model also includes different control variables that can influence the incentives for earnings management:

$$
\begin{aligned}
& E M_{i, t}=\beta_{0}+\beta_{1} \text { Pre-Issue } 2_{i, t}+\beta_{2} \text { Pre } \text { Issue } 1_{i, t}+\beta_{3} \text { Issue }_{i, t} \\
& +\beta_{4}{\text { Post }- \text { Issue }_{i, t}}+\beta_{5} \text { Auditor }_{i}+\beta_{6} \text { Size }_{i, t}+\beta_{7} \text { Growth }_{i, t} \\
& +\beta_{8} \text { Leverage }_{i, t}+\beta_{9} \text { ROA }_{i, t}+\beta_{10} \text { Governance }_{i}+ \\
& \gamma^{\prime} \text { quarter }_{t}+\delta^{\prime} \text { industry }_{j}+\varepsilon_{i, t}
\end{aligned}
$$

In which:

Pre-Issue $2_{i, t}$ : is the dummy variable that takes the value of one (1) for company $i$ two quarters before the debenture issue, and zero ( 0 ) if this is not the case;
Pre-Issue $1_{i, t}$ is the dummy variable that takes the value of 1 for company $i$ in the quarter before the debenture issue, and 0 if this is not the case; 
$I_{s s u e}$ : is the dummy variable that takes the value of 1 for company $i$ in the debenture issuing quarter, and 0 if this is not the case;

Post-Issue $e_{i, t}$ is the dummy variable that takes the value of 1 for company $i$ one quarter after the debenture issue, and 0 if this is not the case.

In Model 5, the dummy variable Post-Issue ${ }_{i, t}$ is the omitted variable, with the intention of avoiding perfect collinearity. Therefore, the coefficients in Pre-Issue ${ }_{i, t}$, Pre-Issue $_{i, t}$ and Issue ${ }_{i, t}$ should be interpreted as differences in relation to the Post-Issue ${ }_{i, t}$ variable. To confirm hypothesis $\mathrm{H}_{2}$, the sign associated with these dummies should be positive and statistically significant.

To test hypothesis $\mathrm{H}_{3}$, which takes possible diffe- rences in company financial performance during the debenture issuing phases into consideration, as well as the level of EM over time, the same specification as Model 5 was used, with the addition of dummy variables indicative of all the phases of debenture issues, as well as the interactive terms of these variables with the company financial variables. The variables used were "auditor", "size", "growth", "leverage", "ROA", and "corporate governance". The interactive terms in this specification showed whether there was a relationship between company financial characteristics and the level of EM in the pre-issue period.

To confirm $\mathrm{H}_{3}$, the coefficients of the interaction term variables should be statistically significant. Similarly, this model was estimated in the following way:

$$
\begin{aligned}
& E M_{i, t}=\beta_{0}+\beta_{1} \text { Pre } \text { Issue } 2_{i, t}+\beta_{2} \text { Pre }- \text { Issue } 1_{i, t}+\beta_{3} \text { Issue }_{i, t} \\
& +\beta_{4} \text { Post }- \text { Issue }_{i, t}+\beta_{5} \text { Auditor }_{i}+\beta_{6} \text { Size }_{i, t}+\beta_{7} \text { Growth }_{i, t}+\beta_{8} \text { Leverage }_{i, t} \\
& +\beta_{9} R O A_{i, t}+\beta_{10} \text { Governance }_{i}+\beta_{k}^{\prime} x_{i, t}^{\prime}+ \\
& \gamma^{\prime} \text { quarter }_{t}+\delta^{\prime} \text { industry }_{j}+\varepsilon_{i, t}
\end{aligned}
$$

In which:

$\beta_{k}^{\prime} x_{i, t}^{\prime}$ is a vector of parameters estimated based on the interactions of the debenture issuing phase dummies with the company financial variables.

In Model 6, again the dummy variable Post-Issue ${ }_{i, t}$ is the omitted variable with the intention of avoiding perfect collinearity. To confirm hypothesis $\mathrm{H}_{3}$, the coefficients associated with the issuing phase interaction dummies with the company financial variables should be statistically significant.

\section{RESULTS}

Table 1 presents the descriptive statistics for the variables that characterize the heterogeneity of the companies. Initially, it is observed that, for these variables, the samples of debenture issuing and non-issuing companies are similar. For example, the average size of the issuing companies is 14.7 million (logarithm of total assets of company $i$ in period $t$ ); the average size for the non-issuing companies is 13.7 million. For the issuing company samples, the average for the ROA variable was $22.1 \%$, while the average for the non-issuing company sample was $23.2 \%$. These differences were not statistically significant.
Additionally, it is possible to observe a similar pattern for other variables, such as sales growth and leverage.

The only aspects in which the two samples are significantly different are: (i) quality of auditor: $47.2 \%$ of issuing companies contracted one of the market leaders (big four), against $31.2 \%$ of the non-issuing companies; and (ii) level of corporate governance: $28.5 \%$ of the issuing companies are listed on the Level II and New Market of corporate governance, against $17.8 \%$ of non-

\begin{tabular}{|c|c|c|c|c|c|c|c|c|c|c|}
\hline & \multicolumn{3}{|c|}{ All } & \multicolumn{3}{|c|}{ Issued Debenture } & \multicolumn{3}{|c|}{ Did not issue debenture } & \multirow[b]{3}{*}{ T- Statistic } \\
\hline & & $N=180$ & & & $N=59$ & & & $N=121$ & & \\
\hline & Median & Mean & $\begin{array}{c}\text { Standard } \\
\text { Deviation }\end{array}$ & Median & Mean & $\begin{array}{c}\text { Standard } \\
\text { Deviation }\end{array}$ & Median & Mean & $\begin{array}{c}\text { Standard } \\
\text { Devia- } \\
\text { tion }\end{array}$ & \\
\hline Sales Growth & 0.024 & 0.031 & 0.045 & 0.030 & 0.031 & 0.034 & 0.010 & 0.031 & 0.054 & 0.00 \\
\hline Leverage & 0.254 & 0.263 & 0.166 & 0.280 & 0.290 & 0.162 & 0.218 & 0.237 & 0.166 & 0.53 \\
\hline ROA & 0.220 & 0.227 & 0.296 & 0.220 & 0.221 & 0.022 & 0.220 & 0.232 & 0.413 & -0.11 \\
\hline Size (billions) & 14.285 & 13.946 & 1.516 & 14.731 & 14.420 & 1.239 & 13.712 & 13.496 & 1.616 & 0.93 \\
\hline Auditor & 0.000 & 0.390 & 0.487 & 0.000 & 0.472 & 0.499 & 0.000 & 0.313 & 0.463 & $0.16^{*}$ \\
\hline Governance & 0.000 & 0.230 & 0.421 & 0.000 & 0.285 & 0.451 & 0.000 & 0.178 & 0.383 & $0.97^{*}$ \\
\hline
\end{tabular}
-issuing companies. These differences are statistically significant to $10 \%$.

Table 1 Descriptive Statistic of Sample Company Financial Characteristics

Note. The "company size" variable is in million reais and refers to the date of data collection, carried out in Nov. 2014; all the data is in 2014 money; the "size" variable is the natural logarithm of Total Assets; the T statistic tests the differences of means between the companies that issued debentures and those that did not.

* indicates statistical significance to a degree of $1 \%$.

Source: Developed by the authors. 
Table 2 presents the correlation between the exogenous variables. In general, the correlations are low, although some are statistically significant to a degree of 1\%. As expected, companies listed on Level II and New Market are positively associated with auditors with good reputations (big four) and tend to be larger companies.
This indicates that companies that decide on these levels of governance opt to contract bigger independent auditors. The "leverage" and "size" variables are positively correlated, indicating that larger companies exhibit higher leverage ratios. Finally, larger companies show higher sales growth rates.

Table 2 Correlation Matrix for Independent Variables

\begin{tabular}{|c|c|c|c|c|c|c|}
\hline & Governance Dummy & Auditor & Growth & Leverage & ROA & Size \\
\hline Governance Dummy & 1 & & & & & \\
\hline Auditor & $0.06^{* *}$ & 1 & & & & \\
\hline Growth & $0.12^{* *}$ & 0 & 1 & & & \\
\hline Leverage & $0.04 * *$ & 0.03 & -0.02 & 1 & & \\
\hline ROA & $0.01 *$ & 0.01 & 0.01 & $0.03^{* *}$ & 1 & \\
\hline
\end{tabular}

Note. ${ }^{*}, * *$ and $* * *$ denote significance to degrees of $10 \%, 5 \%$ and $1 \%$ (for two-tailed tests), respectively.

Source: Developed by the authors.

Table 3 presents descriptive statistics for the level of earnings management, for debenture issuing and non-issuing companies. The results are presented for the two proxies for earnings management, the Modified Jones and the Modified Jones with ROA models. Initially, what stands out is that the averages and standard deviations exhibit little variation for each of the models. Observing the sample as a whole, the average level of EM, measured by current discretionary accruals as a percentage of total assets in the quarter preceding the issue, varies from $3.80 \%$ to $4.08 \%$, depending on the model used. When the sample is divided into issuing and non-issuing companies, the following difference stands out: earnings management in issuing companies varies from $3.80 \%$ to $4.21 \%$, while in non-issuing companies it varies from $3.7 \%$ to $3.96 \%$. This difference is statistically significant to a degree of $10 \%$ (independently of the proxy used for earnings management). This result is consistent with hypothesis $\mathrm{H}_{1}$, that is, debenture issuing companies tend to exhibit greater levels of earnings management.

Table 3 Earnings Management in Debenture Issues

\begin{tabular}{|c|c|c|c|c|}
\hline \multicolumn{5}{|c|}{ Panel A: All the Phases Together } \\
\hline Model & Sample & Companies & Mean & Standard Deviation \\
\hline & All the Companies & 180 & $3.80 \%$ & $3.01 \%$ \\
\hline Modified & Issuing & 59 & $3.80 \%$ & $3.00 \%$ \\
\hline Jones & Non-Issuing & 121 & $3.70 \%$ & $3.02 \%$ \\
\hline & Difference & & $0.10 \% *$ & \\
\hline & All the Companies & 180 & $4.08 \%$ & $3.28 \%$ \\
\hline Modified Jones & Issuing & 59 & $4.21 \%$ & $3.31 \%$ \\
\hline with ROA & Non-Issuing & 121 & $3.96 \%$ & $3.25 \%$ \\
\hline & Difference & & $0.25 \% *$ & \\
\hline
\end{tabular}

Note. Descriptive statistics for the level of earnings management in debenture issues: the sample consists of 180 companies per quarter, with 59 issuing debentures on the BM\&FBOVESPA from Jan. 2010 to Jan. 2014; the two measurements of earnings management are based on the Modified Jones and Modified Jones with ROA models; earnings management is in percentage of total assets; the differences highlighted in bold indicate that the $t$ test for the difference of means is statistically significant to a degree of $10 \%$ or less.

$*, * *$ and $* * *$ denote significance to degrees of $10 \%, 5 \%$ and $1 \%$ (for two-tailed tests), respectively.

Source: Developed by the authors.

Table 4 presents the level of management, considering the issuing phases. It is observed that, on average, earnings management is positive and higher in the debenture pre-issue period, that is, it is greater in the quarter preceding the issue. The phase that considers two quarters that precede the issue does not exhibit statistically different levels of management in relation to non-issuing companies. Thus, the results found indicate that EM is greater in the quarter preceding the issue, the accounting statements for which are generally published during the following quarter, in which the debenture purchase occurs. Thus, these companies aim to show better results in order to influence investors at the time of purchasing debentures. It is important to highlight that the level of management is much lower in the issuing quarter. This indicates that reversion occurs quickly, given that the level of management increases in the pre-issuing phase and falls considerably in the issuing phase.

Table 4 indicates that the average level of earnings management in the pre-issue period is much higher for 
issuing companies, varying from $1.01 \%$ to $1.07 \%$ more in relation to non-issuing companies. The difference in means for the two groups during the pre-issuing phase is statistically significant to a degree of $1 \%$.

Table 4 Earnings Management in Issuing Phases

\begin{tabular}{|c|c|c|c|c|c|c|}
\hline \multirow[t]{2}{*}{ Model } & \multicolumn{2}{|c|}{ Pre-Issue_2 } & \multicolumn{2}{|c|}{ Pre-Issue_1 } & \multicolumn{2}{|c|}{ Issue } \\
\hline & $\mathbf{N}$ & Mean & Difference & Mean & Difference & Mean \\
\hline $\begin{array}{c}\text { Modified } \\
\text { Jones }\end{array}$ & 59 & $3.67 \%$ & $1.01 \% * * *$ & $4.68 \%$ & $-0.47 \%{ }^{* *}$ & $4.21 \%$ \\
\hline $\begin{array}{c}\text { Modified Jones } \\
\text { with ROA }\end{array}$ & 58 & $4.02 \%$ & $1.07 \% * * *$ & $5.09 \%$ & $-0.99 \% * * *$ & $4.10 \%$ \\
\hline
\end{tabular}

Note. Descriptive statistics for the level of earnings management in debenture issues, considering the issuing phases; the sample consists of 180 companies per quarter with 59 issuing debentures on the BM\&FBOVESPA, from Jan. 2010 to Jan. 2014; the two measurements of earnings management are based on the Modified Jones and the Modified Jones with ROA models; earnings management is in percentage of total assets; the differences highlighted in bold indicate that the $t$ test for the difference in means is statistically significant to a degree of $10 \%$ or less.

$*, * *$ and $* * *$ denote significance to degrees of $10 \%, 5 \%$ and $1 \%$ (for two-tailed tests), respectively. Source: Developed by the authors.

Table 5 presents the estimates for the model that includes the dummy variable, which identifies the companies that issued debentures. As expected, the sign of the dummy variable is not statistically significant for any model. This result highlights that there is no statistically significant difference, in terms of EM, between the sample of debenture issuing companies and non-issuing ones. Although this result may conflict with the univariate analysis presented in Table 3, the difference is that the results presented in Table 5 show the difference in terms of EM, considering a set of control variables, which represent the sample company characteristics, such as: sales growth, size, ROA, leverage, auditor dummies and corporate go- vernance. As the signs of these variables exhibit statistical significance, this indicates that the level of EM is related to these characteristics.

If the debenture issuing dummy variable exhibits statistical significance, there would be a model selection problem, since it would not be possible to infer whether the issuing companies exhibit a higher or lower level of EM due to issuing, or because they already exhibit different levels of EM to the non-issuing ones, over time. Thus, given that the samples are similar over time in terms of $\mathrm{EM}$, there is a question to be answered: do companies, in issuing debentures, increase their level of EM in the issuing period?

Table 5 Earnings Management and Debenture Issuing Regressions

\begin{tabular}{|c|c|c|c|c|c|c|}
\hline & \multicolumn{3}{|c|}{ Modified Jones } & \multicolumn{3}{|c|}{ Modified Jones with ROA } \\
\hline & $\begin{array}{l}\text { Least Squares } \\
\text { Method } \\
\text { (1) }\end{array}$ & $\begin{array}{l}\text { Random } \\
\text { Effects } \\
\text { (2) }\end{array}$ & $\begin{array}{l}\text { Fixed } \\
\text { Effects } \\
(3)\end{array}$ & $\begin{array}{l}\text { Least Squares } \\
\text { Method } \\
\text { (4) }\end{array}$ & $\begin{array}{l}\text { Random } \\
\text { Effects } \\
(5)\end{array}$ & $\begin{array}{l}\text { Fixed } \\
\text { Effects } \\
(6)\end{array}$ \\
\hline \multirow[t]{2}{*}{ Issuing dummy } & 0.000 & 0.000 & & 0.002 & 0.002 & \\
\hline & $(0.25)$ & $(0.05)$ & & $(1.32)$ & (1.38) & \\
\hline \multirow[t]{2}{*}{ Governance dummy } & 0.001 & 0.001 & & 0.002 & 0.002 & \\
\hline & $(1.20)$ & $(0.64)$ & & (1.65) & (1.49) & \\
\hline \multirow[t]{2}{*}{ Auditor } & 0.000 & -0.000 & & 0.001 & 0.001 & \\
\hline & $(0.39)$ & $(-0.14)$ & & $(0.55)$ & $(0.55)$ & \\
\hline \multirow[t]{2}{*}{ Growth } & $0.020^{* *}$ & $0.018^{*}$ & $0.018^{*}$ & $0.026^{* *}$ & $0.025^{* *}$ & $0.027^{* *}$ \\
\hline & (1.98) & (1.83) & (1.82) & (2.44) & (2.40) & (2.59) \\
\hline \multirow[t]{2}{*}{ Leverage } & $0.007^{* *}$ & $0.008^{* * *}$ & $0.012^{* * *}$ & 0.005 & 0.005 & 0.007 \\
\hline & $(2.31)$ & $(2.78)$ & (3.11) & $(1.35)$ & $(1.48)$ & (1.58) \\
\hline \multirow[t]{2}{*}{ ROA } & $0.007^{* * *}$ & $0.007^{* * *}$ & $0.008^{* * *}$ & $0.008^{* * *}$ & $0.008^{* * *}$ & $0.007^{* * *}$ \\
\hline & (9.09) & (9.96) & (10.01) & (12.92) & (17.40) & (24.77) \\
\hline \multirow[t]{2}{*}{ Size } & $-0.001^{* * *}$ & $-0.001^{* *}$ & -0.002 & -0.001 & -0.001 & $-0.002^{*}$ \\
\hline & $(-2.65)$ & $(-2.30)$ & $(-1.41)$ & $(-0.98)$ & $(-0.95)$ & $(-1.76)$ \\
\hline Quarterly dummies & Yes & Yes & Yes & Yes & Yes & Yes \\
\hline Cluster per Companies & Yes & Yes & Yes & Yes & Yes & Yes \\
\hline Observations & 4.491 & 4.491 & 4.491 & 4.132 & 4.132 & 4.132 \\
\hline R-squared & 0.0191 & . & 0.00540 & 0.0164 & . & 0.00378 \\
\hline
\end{tabular}

Note. Panel regression analysis of level of earnings management in debenture issues; the dependent variable is the level of earnings management for company $i$ in quarter $t$ as a percentage of total assets; it was calculated using two different models (Modified Jones and Modified Jones with ROA); the sample consists of 4,491 observations for 180 companies per quarter, with 59 issuing debentures on the BM\&FBOVESPA from Jan 2010 to Jan 2014; the $t$ (or z) statistics that are robust in heteroskedasticity via the White (1980) correction method are presented in brackets; moreover, all the regressions were estimated with standard deviation with cluster per company.

$*, * *$ and $* * *$ denote significance to degrees of $10 \%, 5 \%$ and $1 \%$ (for two-tailed tests), respectively.

Source: Developed by the authors. 
Table 6 presents the estimates for the model, which includes the debenture issuing phases as explanatory variables to capture in which phase earnings management is greater for issuing companies, in relation to non-issuing ones. The dummy variable for the post-issue phase is omitted. The dynamic captured in Table 6 is similar to that reported in the univariate analysis (Table 4). The coefficients of the Pre_Issue_ $2_{\mathrm{i}, \mathrm{t}}$, and Issue $_{i, t}$ dummy variables are not statistically significant, except the Pre_Issue_ $1_{\mathrm{i}, \mathrm{t}}$, variable, which is statistically significant to degrees of $5 \%$ and $10 \%$ in all the models (Modified Jones and Modified Jones with ROA) and in all the specifications (Fixed and Random Effects Panel and Pooled OLS). The level of earnings management in the quarter preceding the issue, controlled by the company financial and economic cha- racteristics, is positive and greater in relation to the non-issuing companies.

It stands out that this result is robust with regards to the insertion of different controls, earnings management measures, and statistical methods. The leverage (in line with An et al., 2013), sales growth (as observed by Dechow, Hutton, Kim, \& Sloan, 2012), and ROA (as observed by Silva, Weffort, Flores, \& Silva, 2014; McNichols, 2000; and Kothari et al., 2005) variables exhibit, statistically, a significant and positive effect on the level of earnings management.

The "size" variable was the only one which, being statistically significant, exhibited a negative effect. Finally, the F test, for joint significance of all the explanatory variables for the fixed effect model is statistically significant to a degree of $1 \%$.

Table 6 Earnings Management and Debenture Issuing Regressions

\begin{tabular}{|c|c|c|c|c|c|c|}
\hline & \multicolumn{3}{|c|}{ Modified Jones } & \multicolumn{3}{|c|}{ Modified Jones with ROA } \\
\hline & $\begin{array}{l}\text { Least Squares } \\
\text { Method } \\
\text { (1) }\end{array}$ & $\begin{array}{l}\text { Random } \\
\text { Effects } \\
\text { (2) }\end{array}$ & $\begin{array}{l}\text { Fixed } \\
\text { Effects } \\
(3)\end{array}$ & $\begin{array}{l}\text { Least Squares } \\
\text { Method } \\
\text { (4) }\end{array}$ & $\begin{array}{l}\text { Random } \\
\text { Effects } \\
\text { (5) }\end{array}$ & $\begin{array}{l}\text { Fixed } \\
\text { Effects } \\
(6)\end{array}$ \\
\hline \multirow[t]{2}{*}{ Pre_Issue_2 } & 0.001 & 0.000 & 0.000 & 0.000 & 0.000 & -0.001 \\
\hline & $(0.15)$ & $(0.15)$ & $(0.09)$ & $(0.00)$ & $(0.03)$ & $(-0.14)$ \\
\hline \multirow[t]{2}{*}{ Pre_Issue_1 } & $0.011^{* *}$ & $0.011^{* *}$ & $0.011^{* *}$ & $0.010^{*}$ & $0.010^{*}$ & $0.009^{*}$ \\
\hline & $(2.34)$ & $(2.35)$ & $(2.31)$ & (1.81) & (1.83) & $(\mathbf{1 . 6 5 )}$ \\
\hline \multirow[t]{2}{*}{ Issue } & 0.002 & 0.002 & 0.001 & -0.005 & -0.005 & -0.006 \\
\hline & $(0.42)$ & $(0.35)$ & $(0.22)$ & $(-1.22)$ & $(-1.23)$ & $(-1.26)$ \\
\hline \multirow[t]{2}{*}{ Governance dummy } & 0.001 & 0.001 & & 0.003* & $0.002 *$ & \\
\hline & (1.18) & $(0.68)$ & & $(\mathbf{1 . 8 7})$ & (1.78) & \\
\hline \multirow[t]{2}{*}{ Auditor } & 0.000 & -0.000 & & 0.001 & 0.001 & \\
\hline & $(0.39)$ & $(-0.13)$ & & $(0.66)$ & $(0.60)$ & \\
\hline \multirow[t]{2}{*}{ Growth } & $0.021^{* *}$ & $0.019 *$ & $0.019 *$ & $0.028^{* *}$ & $0.027^{* *}$ & $0.029^{* * *}$ \\
\hline & $(2.05)$ & $(\mathbf{1 . 9 0 )}$ & $(\mathbf{1 . 8 9 )}$ & $(2.58)$ & $(2.53)$ & $(2.69)$ \\
\hline \multirow[t]{2}{*}{ Leverage } & $0.007^{* *}$ & $0.008^{* * *}$ & $0.011^{* * *}$ & 0.005 & 0.005 & 0.007 \\
\hline & $(2.34)$ & $(2.73)$ & (2.98) & (1.35) & $(1.42)$ & $(1.40)$ \\
\hline \multirow[t]{2}{*}{ ROA } & $0.007^{* * *}$ & $0.007^{* * *}$ & $0.008^{* * *}$ & $0.009 * * *$ & $0.008^{* * *}$ & $0.007^{* * *}$ \\
\hline & $(9.31)$ & (10.09) & $(10.02)$ & (11.80) & (16.57) & (24.66) \\
\hline \multirow[t]{2}{*}{ Size } & $-0.001^{* * *}$ & $-0.001 * *$ & -0.002 & -0.001 & -0.000 & $-0.002 *$ \\
\hline & $(-2.77)$ & $(-2.48)$ & $(-1.49)$ & $(-0.94)$ & $(-0.90)$ & $(-1.81)$ \\
\hline Quarterly Dummies & Yes & Yes & Yes & Yes & Yes & Yes \\
\hline Cluster per Companies & Yes & Yes & Yes & Yes & Yes & Yes \\
\hline Observations & 4.585 & 4.585 & 4.585 & 4.218 & 4.218 & 4.218 \\
\hline R-squared & 0.0212 & & 0.0070 & 0.0173 & & 0.0052 \\
\hline
\end{tabular}

Note. Panel regression analysis of level of earnings management in debenture issues; the dependent variable is the level of earnings management for company $i$ in quarter $t$ as a percentage of total assets; it was calculated using two different models (Modified Jones and Modified Jones with ROA); the sample consists of 4,491 observations for 180 companies per quarter, with 59 issuing debentures on the BM\&FBOVESPA from Jan 2010 to Jan 2014; the $t$ (or z) statistics that are robust in heteroskedasticity via the White (1980) correction method are presented in brackets; moreover, all the regressions were estimated with standard deviation with cluster per company.

$*, * *$ and $* * *$ denote significance to degrees of $10 \%, 5 \%$ and $1 \%$ (for two-tailed tests), respectively.

Source: Developed by the authors.

Table 7 presents the results obtained in Table 6, however considering the interactions of the phase dummy variables with each one of the company financial variables. With these interactions, it is possible to analyze which company characteristics better explain the level of management in the debenture pre-issue phase. As can be observed, the most important variable that explains the level of management, in this phase, is sales growth. This result can partly be interpreted by the fact that companies that exhibit higher sales growth rates also have higher margins for managing their earnings. Both in the Modified Jones and in the Modified Jones with ROA model, the Sales Growth interaction variable with the Pre_Issue_1 phase are statistically significant to degrees of $5 \%$ and $10 \%$. The levels of 
management vary positively between $2.66 \%$ and $3.92 \%$. Hochberg (2012) supports the results, in which compa- nies with higher sales growth may be more prone to exhibiting a higher level of discretionary accruals.

Table 7 Earnings Management Regressions Considering Interactions with Issuing Phases

\begin{tabular}{|c|c|c|c|c|c|c|}
\hline & \multicolumn{3}{|c|}{ Modified Jones } & \multicolumn{3}{|c|}{ Modified Jones with ROA } \\
\hline & $\begin{array}{l}\text { Least Squares } \\
\text { Method } \\
\text { (1) }\end{array}$ & $\begin{array}{l}\text { Random } \\
\text { Effects } \\
(2)\end{array}$ & $\begin{array}{l}\text { Fixed } \\
\text { Effects } \\
(3)\end{array}$ & $\begin{array}{l}\text { Least Squares } \\
\text { Method } \\
\text { (4) }\end{array}$ & $\begin{array}{l}\text { Random } \\
\text { Effects } \\
\text { (5) }\end{array}$ & $\begin{array}{l}\text { Fixed } \\
\text { Effects } \\
(6)\end{array}$ \\
\hline \multirow[t]{2}{*}{ Pre_Issue_2 } & -0.003 & -0.003 & -0.003 & -0.004 & -0.003 & -0.004 \\
\hline & $(-0.67)$ & $(-0.59)$ & $(-0.60)$ & $(-0.78)$ & $(-0.68)$ & $(-0.71)$ \\
\hline \multirow[t]{2}{*}{ Issue } & 0.003 & 0.002 & 0.002 & -0.003 & -0.003 & -0.004 \\
\hline & $(0.47)$ & $(0.37)$ & $(0.27)$ & $(-0.43)$ & $(-0.45)$ & $(-0.57)$ \\
\hline \multirow[t]{2}{*}{ Pre Issue 1 Auditor } & 0.000 & 0.001 & 0.001 & 0.004 & 0.004 & 0.004 \\
\hline & $(0.00)$ & $(0.12)$ & $(0.09)$ & $(0.37)$ & $(0.38)$ & $(0.36)$ \\
\hline \multirow[t]{2}{*}{ Pre Issue 1 Governance } & -0.004 & -0.007 & -0.008 & -0.015 & $-0.020^{*}$ & $-0.023^{*}$ \\
\hline & $(-0.39)$ & $(-0.70)$ & $(-0.81)$ & $(-1.34)$ & $(-1.71)$ & $(-1.95)$ \\
\hline Pre Issue 1 Growth & $0.289 *$ & $0.274 *$ & $0.266^{*}$ & $0.392 * *$ & $0.374 *$ & $0.378^{*}$ \\
\hline \multirow[t]{2}{*}{ Pre Issue 1 Leverage } & -0.011 & -0.010 & -0.008 & $-0.057^{*}$ & $-0.057^{*}$ & -0.049 \\
\hline & $(-0.36)$ & $(-0.35)$ & $(-0.28)$ & $(-1.90)$ & $(-1.90)$ & $(-1.60)$ \\
\hline \multirow[t]{2}{*}{ Pre Issue 1 ROA } & 0.018 & -0.063 & -0.114 & 0.014 & -0.104 & -0.155 \\
\hline & $(0.05)$ & $(-0.17)$ & $(-0.32)$ & $(0.03)$ & $(-0.26)$ & $(-0.38)$ \\
\hline \multirow[t]{2}{*}{ Pre Issue 1 Size } & 0.000 & -0.001 & -0.002 & 0.001 & -0.000 & -0.001 \\
\hline & $(0.04)$ & $(-0.15)$ & $(-0.29)$ & $(0.17)$ & $(-0.07)$ & $(-0.21)$ \\
\hline Quarterly Dummies & Yes & Yes & Yes & Yes & Yes & Yes \\
\hline Cluster per Companies & Yes & Yes & Yes & Yes & Yes & Yes \\
\hline Observations & 2.517 & 2.517 & 2.517 & 2.294 & 2.294 & 2.294 \\
\hline R-squared & 0.0244 & & 0.0023 & 0.0280 & & 0.0045 \\
\hline
\end{tabular}

Note. Panel regression analysis of level of earnings management in debenture issues, considering the interactions of company characteristic variables with the Pre Issue 1 variable, which corresponds to the quarter that precedes the debenture issue; the dependent variable is the level of earnings management for company $i$ in quarter $t$ as a percentage of total assets; it was calculated using two different models (Modified Jones and Modified Jones with ROA); the sample consists of 4,491 observations for 180 companies per quarter, with 59 issuing debentures on the BM\&FBOVESPA from Jan. 2010 to Jan. 2014; the $t$ (or z) statistics that are robust in heteroskedasticity via the White (1980) correction method are presented in brackets.

$*, * *$ and $* * *$ denote significance to degrees of $10 \%, 5 \%$ and $1 \%$ (for two-tailed tests), respectively.

Source: Developed by the authors.

Finally, for robustness effects, the Propensity Score Matching (PSM) method was used to minimize the selection problems that could cause bias in the results in the samples of this study. This methodology aims to take control groups and give comparable treatments. For this, it seeks to homogenize the spread of different variables between groups.

The Matching was estimated considering similar companies in terms of size, leverage, and profitability. The idea of choosing these variables is that it is expected that companies of similar size, degrees of leverage, and profitability also exhibit similar levels of EM. Thus, it is possible to control observable characteristics that could cause bias in the results already found. Hence, the difference would be the issuing of debentures. Table 8 presents the earnings management analysis considering this method. As can be observed, the level of management is positive and statistically significant to a degree of $10 \%$. The debenture issuing companies exhibit a positive level of EM, which varies between $0.9 \%$ and $1 \%$ in the phase that precedes the issue. Both in the pre-issue phrases, considering two quarters, and in the issue phase, there are no statistically significant differences in terms of earnings management.

\begin{tabular}{|c|c|c|c|c|c|c|}
\hline & Pre_Issue_2 & Pre_Issue_1 & Issue & Pre_Issue_2 & Pre_Issue_1 & Issue \\
\hline & -0.001 & 0.009 & 0.004 & -0.000 & 0.010 & 0.000 \\
\hline & $(0.23)$ & $(1.74)^{*}$ & $(0.83)$ & $(0.08)$ & $(1.74)^{*}$ & $(0.06)$ \\
\hline$N$ & 5.179 & 5.179 & 5.179 & 4.778 & 4.778 & 4.778 \\
\hline
\end{tabular}

Note. For each one of the issues a matching was carried out with one company from the same sector with similar profitability, leverage, and sales growth, however which had not issued debentures; the dependent variable is the level of earnings management for company $i$ in quarter $t$ as a percentage of total assets; it was calculated using two different models (Modified Jones and Modified Jones with ROA); the sample consists of 4,491 observations for 180 companies per quarter, with 59 issuing debentures on the BM\&FBOVESPA from Jan. 2010 to Jan. 2014; the $\mathrm{t}$ (or z) statistics that are robust in heteroskedasticity via the White (1980) correction method are presented in brackets. $*, * *$ and $* * *$ denote significance to degrees of $10 \%, 5 \%$ and $1 \%$ (for two-tailed tests), respectively. Source: Developed by the authors. 


\section{FINAL REMARKS}

In light of the assumptions and suppositions of the literature on earnings management, and its motivations and consequences, the aim of this study was to evaluate EM practices in debt security issuing periods, identifying in which debenture issuing period these interventions are carried out, in order to positively influence investors. This influence may result in investors not being able to make the best possible decisions based on the financial results presented by these companies. Thus, investors may be induced into buying debt securities of companies that do not have good financial conditions, possibly generating negative results in the future.

The study used current discretionary accruals as a proxy for earnings management, derived from the Modified Jones and Modified Jones with ROA models (Dechow et al., 1995 with adjustments suggested by Kothari et al., 2005). Moreover, other control variables were specified.

With regards to the results, it was found that, as well as the debt pre-issue phase 1, leverage, sales growth, and ROA were variables that exhibited a positive and statistically significant effect on the level of earnings management. The only variable that exhibited a negative, statistically significant effect, was the "size" variable.

The sign of the debenture issuing dummy variable, tested in the first hypothesis, does not exhibit statistical significance for any model. This result reinforces, as expected, there being no statistically significant difference, in terms of EM, between the sample of issuing companies and non-issuing companies.

In relation to the results regarding the study's second hypothesis, which aimed to analyze the EM dynamic at the time of issuing debentures, these allowed for non rejection of this hypothesis. The results showed that the quarter that exhibited the greatest level of management was that preceding the issue.

After examining the period in which there is the greatest level of earnings management, hypothesis 3 was investigated - which variable, interacting with the dummy regarding the quarter preceding the issue, would stand out. Both in the Modified Jones and in the Modified Jo- nes with ROA model, the Sales Growth interaction variable is statistically significant to degrees of $5 \%$ and $10 \%$. Thus, the most important variable that explained the level of management in the period was sales growth. This result can partly be explained by the fact that companies that exhibit higher sales growth rates also have higher margins for managing their earnings. This result leads to the confirmation of hypothesis 3, which states that there is a relationship between the level of EM and company financial characteristics.

Therefore, it became clear that debenture issuing companies managed their earnings in the quarter preceding the issue. Thus, the results found show that these companies tend to exhibit greater levels of earnings management in the phase in which investors are attracted to purchasing debentures. These companies aim to present better results in order to influence investors at the time of purchase. The companies that exhibit a greater level of earnings management in the phase in which investors opt to acquire debentures are those that exhibit a higher level of sales growth. This occurs due to the higher margin that these companies have in managing their financial results.

As a result of this practice, investors may be induced into buying debt securities of companies that have poor financial results, which due to the practicing of EM, end up being inflated. In the short run, the holders of these securities may be disadvantaged for not being able to better evaluate the results presented in the period of acquiring these debentures. In the long run, these companies will need to reverse the inflated results in the debenture sale period. This reversion can generate even greater losses for investors who want to trade their debentures on the secondary market. Therefore, it is up to regulatory bodies to propose monitoring measures that minimize the information asymmetry there is between investors and issuing companies at the time of issuing debentures.

Subsequent studies could address other offerings, such as Seasoned Equity Offerings (SEO), in order to better understand the earnings management dynamic of companies listed on the BM\&FBOVESPA. 


\section{References}

An, Z., Li, D., \& Yu, J. (2013). Earnings management, capital structure and the role of institutional environments. Financial Research Network Research Paper. Retrieved from SSRN: http://ssrn.com/ abstract=2207804 ou http://dx.doi.org/10.2139/ssrn.2207804 .

Associação Brasileira das Entidades dos Mercados Financeiros e de Capitais (2014). Consolidated data. Retrieved on November 8th 2014, from http://www.debentures.com.br/dadosconsolidados/ comparativovaloresmobiliarios.asp.

Bharath, S. T., Sunder, J., \& Sunder,.S. V. (2008). Accounting quality and debt contracting. The Accounting Review, 83(1), 1-28.

Bowen, R., Rajgopal, S., \& Venkatachalam, M. (2008). Accounting discretion, corporate governance and firm performance. Contemporary Accounting Research, 25(2), 351-405.

Burgstahler, D., \& Dichev, I. (1997).. Earnings management to avoid earnings decreases and losses. Journal of Accounting and Economics, 24(1), 99-126.

Coelho, A. C. D., \& Lopes, A. B. (2007). Avaliação da prática de gerenciamento de resultados na apuração de lucro por companhias abertas brasileiras conforme seu grau de alavancagem financeira. Revista de Administração Contemporânea, 11(2), 121-144.

Cohen, D. A., \& Zarowin, P. (2010). Accrual-based and real earnings management activities around seasoned equity offerings. Journal of Accounting and Economics, 50(1), 2-19.

Cupertino, C. M. (2013). Gerenciamento de resultados por decisões operacionais no mercado brasileiro de capitais. Doctoral thesis, Programa de Pós-Graduação em Administração da Universidade Federal de Santa Catarina, Florianópolis; SC, Brasil:

Dechow, P. M., Hutton, A. P., Kim, J. H., \& Sloan, R. G. (2012). Detecting earnings management: A new approach. Journal of Accounting Research, 50(2), 275-334.

Dechow, P. M., Sloan, R. G., \& Sweeney, A. P. (1995). Detecting earnings management. Açcounting Review, 70(2), 1.93-225.

Easley, H., \& O'Hara, M. (2004). Information and the cost of capital. The Journal of Finance, 59(4), 1553-1583.

Ge, W. (2009). Essays on real earnings management. Doctoral Dissertation - Desautels Faculty of Management, McGill University, Montreal, Canada.

Ge, W., \& Kim, J. B. (2014). Real earnings management and the cost of new corporate bonds. Journal of Business Research, 67(4), 641-647.

Gioielli, S. P. O., Carvalho, A. G., \& Sampaio, J. O. (2013). Capital de risco e gerenciamento de resultados em IPOs. Brazilian Business Review, $10(4), 32-68$

Graham, J. R., Harvey, C. R., \& Rajgopal, S. (2005). The economic implications of corporate financial reporting. Journal of Accounting and Economics, 40(1), 3-73.

Guay, W. R., Kothari, S. P., \& Watts, R. L. (1996)..A market-based evaluation of discretionary accruals model. Journal of Accounting Research, 34, 83-105.

Healy, P. M. (1985). The effect of bonus schemes of accounting decisions. Journal of Accounting and Economics, 7(1), 85-107.

Healy, P. M., \& Wahlen, J. M. (1999). A review of the earnings management literature and its implications for standard setting. Accounting Horizons, 13(4), 365-383.

Hochberg, Y. V. (2012). Venture Capital and Corporate Governance in the Newly Public Firm. Review of Finance, 16(2), 429-480.

Iudicibus, S., \& Lopes, A. B. (2004). Teoria Avançada da Contabilidade. São Paulo: Atlas,

Jones, J. J. (1991). Earnings management during import relief investigations. Journal of Accounting Research, 29(2), 193-228.

Kim, J. B., \& Sohn, B. C. (2013). Real earnings management and cost of capital. Journal of Accounting and Public Policy, 32(6), 518-543.

Kothari, S. P., Leone, A. J., \&.Wasley, C. E. (2005). Performance matched discretionary accrual measures. Journal of Accounting and Economics, 39(1), 163-197.

Liu, Y., Ning, Y., \& Davidson III, W. N. (2010). Earnings Management Surrounding New Debt Issues. The Financial Review, 45, 659-681.

Martinez, A. L. (2001). Gerenciamento dos resultados contábeis: estudo empírico das companhias abertas brasileiras. Tese de doutorado, Faculdade de Economia, Administração e Contabilidade, Universidade de São Paulo, São Paulo, SP, Brasil.

Martinez, A. L., \& Faria, M.P. (2007). Emissão de debêntures e earnings management no Brasil. Revista de Informação Contábil; 2(1), 57-71.

McNichols, M. (2000). Research design issues in earnings management studies. Journal of Accounting and Public Policy, 19(4), 313-345.

Morsfield, S. G., \& Tan, C. E. L. (2006). Do venture capitalists influence the decision to manage earnings in initial public offerings? Accounting Review, 81(5), 1119-1150.

Nardi, P. C. C., \& Nakao, S. H. (2009). Gerenciamento de resultados e a relação com o custo da dívida das empresas brasileiras abertas. Revista Contabilidade \& Finanças, 20(50), 77-100.

Prevost, A. K., Rao, R. P., \& Skousen, C. J. (2008). Earnings Management and the Cost of Debt. Available at SSRN: http://ssrn.com/ abstract=1083808 ou http://dx.doi.org/10.2139/ssrn.1083808.

Rangan, S. (1998). Earnings management and the performance of seasoned equity offerings. Journal of Financial Economics, 50(1), 101-122.

Schipper, K. (1989). Commentary on earnings management. Accounting Horizons, 3(4), 91-102.

Scott, W. R. (2011). Financial Accounting Theory (6th ed.). Upper Saddle River, N.J.: Prentice Hall.

Silva, A. F., Weffort, E. F. J., Flores, E. S., \& Silva, G. P. (2014). Earnings management and economic crises in the Brazilian capital market. Revista de Administração de Empresas, 54(3), 268-283.

Teoh, S. H., Welch, I., \& Wong, T. J. (1998). Earnings management and the long-run market performance of initial public offerings. The Journal of Finance, 53(6), 1935-1974.

White, H. (1980). A heteroskedastiçity-consistent covariance matrix estimator and a direct test for heteroskedasticity. Econometrica, 48(4), 817-838:

Zang, A. Y. (2012). Evidence on the trade-off between real activities manipulation and accrual-based earnings management: The Accounting Review, 87(2), 675-703.

\section{Correspondence Address:}

\section{Bianca Piloto Sincerre}

Pontifícia Universidade Católica de São Paulo, Departamento de Pós-Graduação em Administração

Rua Ministro Godoy, 969, $4^{\circ}$ andar, sala 4E-04 - CEP: 05015-901

Perdizes - São Paulo - SP

Email: bianca.sincerre@gmail.com 